Elżbieta Pakszys

Uniwersytet im. Adama Mickiewicza w Poznaniu

\title{
Transgresja albo przekraczanie granic: Wybitne kobiety w nauce wczoraj i dziś
}

\begin{abstract}
Transgresja jest pojęciem wieloznacznym stosowanym w różnych dzie_ dzinach na określenie zjawisk lub procesów przekraczania wcześniej rozpoznanych barier i ograniczeń. W geografii, tudzież geologii, używa się go, gdy mowa o wodach przekraczających stały ląd, z kolei w biologii, a zwłaszcza w genetyce, określa ono zjawisko przekraczania u potomstwa zakresu zmienności cech odziedziczonych po rodzicach. W refleksji krytycznoliterackiej, jak podkreśla Maria Janion, transgresja stosowana jest do opisu stanów liminalnych, którym podlega jednostka ludzka, a do których zaliczyć można: skrajne osamotnienie, deprywację, transseksualność, wielość osobowości czy bycie innym(ą) ${ }^{1}$. W swoich rozważaniach odwołuję się jednak głównie do Józefa Kozieleckiego, który w latach osiemdziesiątych i dziewięćdziesiątych XX wieku rozwinął koncepcję transgresji na gruncie psychologii, wpisując się w ramy nurtu określanego mianem psychotransgresjonizmu. Jako roboczą przyjmuję więc definicję transgresji, wyrażoną w jednej z ostatnich prac tego autora. Stwierdza on, że:
\end{abstract}

Działania transgresyjne polegają na tym, że człowiek świadomie przekracza dotychczasowe granice materialne, społeczne i symboliczne [...]. Wykraczanie poza granice, w których działała jednostka i zbiorowość, to jakby kolejne akty stwarzania - lub przynajmniej poszerzania - świata. Czynności te mogą być źródłem rozwoju lub regresu².

Transgresja w ujęciu Kozieleckiego może zostać wykorzystana do opisu i analizy cech osobowości oraz przebiegu linii życia wybitnych jednostek, które charakteryzują się szczególną dynamiką, odkrywczością, zmiennością trajektorii biografii, a w rezultacie, uzyskanym wpływem i znaczeniem. W psychologii rozpoznawane są osobowości „transgresyjne” i przeciwstawiane im typy „zachowawcze” lub „adaptacyjne”, na przykład Thomas Edison a Gonczarowowski Ilia Iljicz Obłomow. Z tzw. przeciętnymi zjadaczami

${ }^{1}$ Maria Janion, Kobiety i duch inności, Sic!, Warszawa 1996.

2 Józef Kozielecki, Transgresja i kultura, Wydawnictwo Akademickie „Żak”, Warszawa 1997, s. 43. 
chleba konfrontowani być mogą Lech Wałęsa lub Nelson Mandela, ale też Józef Stalin, Adolf Hitler i Anders Breivik. Ich udziałem są bowiem transgresje psychologiczne (typ P) oraz transgresje historyczne (typ H). Pierwsze obejmują indywidualne i twórcze przezwyciężanie, przekraczanie napotykanych w trakcie jednostkowego życia ograniczeń, barier i kryzysów. Drugie, mające szerszy wymiar, znaczone są odnoszeniem sukcesów oraz wywieraniem wpływu na wszelkich możliwych polach. Oznaczają odciskanie śladów o historycznym zasięgu; w przeważającej mierze chodzi tu o powszechnie uznane osiągnięcia (odkrycia, wynalazki itp.), ale nie tylko.

Transgresja zatem to pewna złożona sytuacja (ciąg zdarzeń, proces) rozgrywająca się na następujących poziomach: (1) jednostki ludzkiej, a więc psychiczna, indywidualna, subiektywna; (2) grupy społecznej, kiedy dotyczy zbiorowości (ograniczonej przestrzennie lub rozproszonej, jak chociażby w przypadku określonego pokolenia kobiet w nauce); (3) kulturowym, gdy transgresja manifestuje się społecznie $\mathrm{w}$ danym kontekście historycznym poprzez zdolność do twórczego przekraczania rozpoznanych ograniczeń (w każdym możliwym wymiarze).

Trwające od połowy XIX wieku stopniowe wchodzenie kobiet w przestrzeń publiczną, głównie za sprawą możliwości kształcenia się i obierania przez nie zawodów twórczych, wiąże się z naruszaniem i przekraczaniem uświęconych tradycją ról społecznych i zwyczajów, jak również instytucji. Konsekwencją tego jest wychodzenie poza społeczne funkcje podstawowe (prokreacyjną i reprodukcyjną), które dotychczas lokowały kobiety nieodmiennie w sferze prywatnej. Sytuację przerywania i przekraczania takiego ciągu determinacji nazywam transgresją. Przybiera ona charakter wąski, elitarny wtedy, gdy dotyczy rozróżnialnych pokoleń w nauce lub szkół filozoficznych. Rozwinąć się może w transgresję zbiorową, historyczną, kiedy chociażby w XX i XXI wieku kobiety, stanowiące połowę rodzaju ludzkiego, uwidaczniają się na arenie dziejów. Taką sytuację rozważa się również obecnie w ramach psychologii transgresyjnej ${ }^{3}$.

Począwszy od XVII wieku kobiety uprawiające różne dyscypliny wiedzy stają się coraz bardziej widoczne, wychodząc poza rolę in/visible assistent - pomocnicy wspomagającej pracę badawczą mężczyzn, zazwyczaj w konfiguracji rodzinnej. Funkcjonując na obrzeżach oficjalnej nauki, ustanawiają kulturowe podstawy pod samodzielną działalność badaczek w następnych

${ }^{3}$ Zob.: Monika Majewska, Aktywizm wspótczesnej kobiety na tle koncepcji K. Popielskiego i J. Kozieleckiego, [w:] red. Irena Pufal-Struzik, O przekraczaniu granic wtasnych ograniczeń - perspektywa psychotransgresjonizmu, Impuls, Kraków 2008, s. 145-157; Irena Pufal-Struzik, Wewnętrzne i zewnętrzne bariery przedsiębiorczości i twórczego rozwoju kobiet z perspektywy transgresjonizmu, [w:] red. Bogna Bartosz, Alicja Keplinger, Maria Straś-Romanowska, Transgresje - innowacje - twórczość, Wydawnictwo Uniwersytetu Wrocławskiego, Wrocław 2011, s. 295-309. 
stuleciach ${ }^{4} \mathrm{~W}$ wyniku badań nad obecnością kobiet w nauce na przełomie XIX i XX wieku, ze szczególnym uwzględnieniem szkoły lwowsko-warszawskiej (polskiej wersji filozofii analitycznej) oraz postaci Marii Skłodowskiej-Curie, uzyskałam wstępny obraz transgresyjnego przebiegu karier zawodowych i, szerzej, biografii badaczek ${ }^{5}$. Najlepszym, gdyż najwnikliwiej rozpoznanym przykładem biografii transgresyjnej wydaje się obecnie biografia podwójnej noblistki.

Grażyna Mendecka, analizując trajektorię życia Marii Skłodowskiej-Curie, wyodrębniła pięć typów transgresji: (1) edukacyjną, związaną ze zdobywaniem wiedzy, uzyskaniem przez badaczkę niezwykle wysokich kwalifikacji w dziedzinach fizykochemicznych; (2) odkrywczą, czyli wynalazczość w zakresie nauki; (3) organizacyjną, przejawiającą się na przykład $\mathrm{w}$ zorganizowaniu w latach dwudziestych i trzydziestych XX wieku pierwszego nowoczesnego laboratorium, a wcześniej, w trakcie pierwszej wojny światowej, uruchomienie medycznej służby rentgenowskiej; (4) transgresję w zakresie społecznej praktyki życiowej - umiejętnego połączenia roli badaczki i matki, która po śmierci męża Piotra Curie samotnie wychowywała dwie córki; (5) transgresję w zakresie obyczajowości - walka Skłodowskiej-Curie o rozdzielenie spraw zawodowych od życia prywatnego, kiedy jej romans z żonatym Paulem Langevinem stał się pretekstem do publicznej nagonki, podczas której domagano się nieprzyznania jej drugiej Nagrody Nobla w $1911 \mathrm{roku}^{6}$. Ta niemalże modelowo przedstawiona biografia może posłużyć za wzorzec dla podobnych, będących udziałem innych badaczek, choć każda z nich nosi indywidualne rysy.

Przedstawione poniżej jedynie szkicowo przypadki obejmują postaci uczonych kobiet związanych z nowożytną kulturą polską. Listę otwierają siedemnastowieczne „amatorki astronomii”, wśród nich Maria Cunitz i Elżbieta Heweliuszowa, oraz aktywne w XIX stuleciu „amatorki filozofii” - Eleonora Ziemięcka i Eliza Orzeszkowa. Ich status wynikał z tego, że nie miały możliwości uzyskania systematycznego wykształcenia w dziedzinach, które

${ }_{4}$ Elżbieta Pakszys, Danuta Sobczyńska, Przedmowa, [w:] red. eadem, Kobiety w poznaniu naukowym wczoraj i dziś, seria Humanistyka i pleć, tom 2, Wydawnictwo Naukowe UAM, Poznań 1997, s. 9-21; Natalie Zemon Davis, Metamorfozy. Maria Sybilla Merian, [w:] eadem, Kobiety na marginesach. Trzy siedemnastowieczne życiorysy, przel. Bartosz Hlebowicz, Wydawnictwo Naukowe PWN, Warszawa 2012, s. 147-209.

${ }^{5}$ Por. chociażby: Elżbieta Pakszys, Kobiety w filozofii polskiej. Dwa pokolenia kobiet Szkoty Lwowsko-Warszawskiej, [w:] red. Elżbieta Pakszys, Danuta Sobczyńska, Kobiety $w$ poznaniu naukowym wczoraj i dziś, seria Humanistyka i pteć, tom 2, Wydawnictwo Naukowe UAM, Poznań 1997, s. 173-191.

${ }^{6}$ Grażyna Mendecka, Transgresyjna biografia Marii Skłodowskiej-Curie, [w:] red. Bogna Bartosz, Alicja Keplinger, Maria Straś-Romanowska, Transgresje - innowacje twórczość, Wydawnictwo Uniwersytetu Wrocławskiego, Wrocław 2011, s. 442. 
zgłębiały i uprawiały w znacznym stopniu samodzielnie7. Dopiero pokolenie Marii Skłodowskiej-Curie (1867-1934), kobiet urodzonych po powstaniu styczniowym 1863 roku, stanowi pierwszą generację, która uzyskała i wykorzystała szansę na transgresję w zakresie kształcenia, zdobywając dyplomy zagranicznych uczelni, co przekładało się na możliwości profesjonalnego funkcjonowania w nauce.

Tab. 1. Pierwsze pokolenia kobiet w nauce i filozofii polskiej (lub związane z kulturą polską)

\begin{tabular}{|c|c|}
\hline \multicolumn{2}{|c|}{ Amatorki astronomii: } \\
\hline \multicolumn{2}{|c|}{ Maria Cunitz (1610-1667), Elżbieta Koopman-Heweliuszowa (1647-1693) } \\
\hline \multicolumn{2}{|c|}{ Amatorki filozofii: } \\
\hline \multicolumn{2}{|c|}{ Eleonora z Gatkiewiczów Ziemięcka (1815/19-1869), Eliza Orzeszkowa (1841-1910) } \\
\hline Nauki przyrodnicze: & Nauki humanistyczne: \\
\hline $\begin{array}{l}\text { Fizykochemia, promieniotwór- } \\
\text { czość: } \\
\text { Maria Skłodowska-Curie (1867-1934) }\end{array}$ & $\begin{array}{l}\text { Filozofia i nauki społeczne: } \\
\text { Józefa z Krzyżanowskich Kodisowa } \\
\text { (1865-1940) } \\
\text { Szkoła lwowsko-warszawska (I pokolenie): } \\
\text { Aniela Szycówna (1869-1921) } \\
\text { Felicja Nossig-Próchnikowa (1855-1939) } \\
\text { Salomea Perlmutter (1865-1936) }\end{array}$ \\
\hline \multirow[t]{2}{*}{$\begin{array}{l}\text { Medycyna, fizjologia, pedologia: } \\
\text { Józefa Joteyko (1868-1929) }\end{array}$} & $\begin{array}{l}\text { Filozofia społeczna i polityczna: } \\
\text { Zofia Daszyńska-Golińska (1866-1934) } \\
\text { Róża Luksemburg (1871-1919) }\end{array}$ \\
\hline & $\begin{array}{l}\text { Antropologia kulturowa: } \\
\text { Maria Antonina Czaplicka (1884-1921) }\end{array}$ \\
\hline \multicolumn{2}{|c|}{ Kobiety w szkole lwowsko-warszawskiej (II pokolenie) } \\
\hline \multicolumn{2}{|c|}{$\begin{array}{l}\text { Daniela Tennerówna-Gromska (1889-1873) } \\
\text { Maria Ossowska (1896-1974) } \\
\text { Janina Hosiasson-Lindenbaumowa (1899-1942) } \\
\text { Janina Kotarbińska (Dina Sztejnbarg) (1901-1997) } \\
\text { Seweryna Łuszczewska-Romahnowa (1904-1970) } \\
\text { Izydora Dąmbska (1904-1983) } \\
\text { Eugenia Ginsberg-Blausteinowa (1905-1942/4) } \\
\text { Maria Kokoszyńska-Lutmanowa (1905-1981) } \\
\text { Irena Filozofówna (1906-1967) }\end{array}$} \\
\hline
\end{tabular}

Zaproponowane w badaniach kryteria rozpoznawania ich sytuacji intersekcjonalna analiza ich biografii - obejmują zasadniczo następujące aspekty społeczne i kulturowe: (1) status i pochodzenie społeczne oraz etniczne; (2) (trafny) wybór dyscypliny badawczej; (3) stan cywilny i sytuację

7 Elżbieta Pakszys, Przekraczanie granic: uwarunkowania sukcesu kobiet $w$ Poznaniu, „Etyka” 2012, nr 45, s. 99-105. 
rodzinną (małżeństwo lub panieństwo, macierzyństwo); (4) siostrzeństwo, solidarność genderową, wsparcie i wzorce osobowe innych kobiet. W dalszej części artykułu krótko omówię wyodrębnione kategorie analizy intersekcjonalnej.

Status i pochodzenie społeczne, uplasowanie w rozpoznawanej stratyfikacji, okazuje się zmienne między innymi za sprawą zwiększającej się mobilności jednostek, w tym kobiet, w społeczeństwach stanowych XIX wieku. Wchodzące wówczas w nowe role kobiety charakteryzują się dużą mobilnością wertykalną (podobnie jak mężczyźni), wynikającą z wejścia w obszar „republiki nauki”. Sfera ta była w dużej mierze autonomiczna, choć wykazywała związki z władzą polityczną i industrialną, które z kolei podlegały autorytetowi Akademii i instytucji międzynarodowych, wówczas skrajnie zmaskulinizowanych i patriarchalnych.

W przebadanych dotychczas przypadkach kobiety wywodzą się zasadniczo ze szlachty - klasy pierwotnie ekonomicznie uprzywilejowanej, w drugiej połowie XIX wieku (zwłaszcza po powstaniu styczniowym) na ogół już zbiedniałej, wykonującej zawody nauczycielskie i urzędnicze, przez co sprowadzonej do warstwy inteligencji. Kształcenie dzieci, także córek, uznawano w takich rodzinach za istotną przesłankę ich samorealizacji lub rodzaj posagu, stąd wspieranie ich aspiracji do edukacji uniwersyteckiej przy założeniu istnienia szans na przyszłe jej wykorzystanie w pracy zawodowej. W ten sposób kształtowała się droga transgresji edukacyjnej Marii Skłodowska-Curie, Józefy Joteyko i Marii Antoniny Czaplickiej.

W omawianej kategorii mieści się również od mien ność et niczna. Wiele z badanych kobiet reprezentowało bowiem mniejszości, legitymując się na przykład, mało dotychczas uwzględnianym w badaniach, pochodzeniem żydowskim. W tym czasie wśród Żydów aspiracje edukacyjne kobiet - mimo częstych ograniczeń ze strony tradycji patriarchalnej - wyraźnie się nasilają. W pierwszym pokoleniu kobiet szkoły lwowsko-warszawskiej dotyczy to Felicji Nossig-Próchnikowej i Salomei Perlmutter oraz, nie przynależnej do tej formacji, Róży Luksemburg. Podobne tendencje ujawniają się w drugim pokoleniu kobiet filozoficznej szkoły lwowsko-warszawskiej, gdzie niemal połowę jej przedstawicielek stanowią Żydówki, w tym Janina Hosiasson-Lindenbaum, Janina Kotarbińska (Dina Sztejnbarg) oraz Eugenia Ginsberg-Blausteinowa.

Trafność obranej i z powodzeniem uprawianej dyscypliny, jej prestiż i znaczenie to czynniki zmienne historycznie, wyznaczane tradycją środowisk i instytucji naukowych. Stanowią zagadnienie szczególnie złożone w interpretacji, zwłaszcza z powodu trudności w porównywaniu sposobów osiągania sukcesu w naukach przyrodniczych i humanistycznych. Zastosowany tutaj podział na dziedziny podstawowe i stosowane, 
jak fizykochemia i fizyka promieniotwórczości, określa ich fundamentalne znaczenie dla wykorzystania przemysłowego czy militarnego, pomimo ich zasadniczych celów poznawczych. Taki jest przypadek promieniotwórczości naturalnej odkrytej przez Marię Skłodowską-Curie, której znaczenie wiązało się zarówno z rozpoznaniem struktury atomu, jak i późniejszymi zastosowaniami uzyskanej wiedzy do jego rozbijania w celu pozyskiwania energii. Także przecież nauki medyczne pozostają w ścisłych związkach z bardziej podstawowymi naukami biologicznymi. W tym kontekście warto wspomnieć badania Józefy Joteyko, niezmiernie cenione w swoim czasie, ale przecież niewspółmierne wobec osiągnięć podwójnej noblistki. Pierwszoplanowy zaś cel poznawczy takich dziedzin, jak etnografia i etnologia (antropologia kulturowa) z pewnością wzrastał w miarę możliwości gospodarczego i politycznego wykorzystania ich wyników jako wiedzy koniecznej do zarządzania ludami kolonizowanymi. Dowodzi tego przykład Marii Antoniny Czaplickiej, badaczki ludów Syberii, która na swoje badania musiała zdobywać niemałe kwoty od bezpośrednio zainteresowanych placówek i fundacji.

Próby przeprowadzania rankingu za pomocą kryterium, jakim jest chociażby liczba publikacji wydają się chybione, gdyż ranga odkryć naukowych nie przekłada się łatwo na miarę ilościową (dzisiaj stanowiącą fetysz i doprowadzoną niemal do absurdu). Jedynie w ramach tej samej lub pokrewnej dyscypliny takie zestawienia mogą okazać się zasadne. Stosując je jednak, należy pamiętać o efekcie niezależnych czynników, jak chociażby długość i warunki życia. Możliwość pełnej samorealizacji była udziałem na przykład kobiet drugiego pokolenia szkoły lwowsko-warszawskiej. Jej liderki (Maria Ossowska i Izydora Dąmbska), pomimo wojennej traumy, miały przywilej długiego życia. Życie i kariera zawodowa ich koleżanek i rówieśnic żydowskiego pochodzenia (Janina Hosiasson-Lindenbaumowa i Eugenia Ginsberg-Blausteinowa) zostały natomiast przerwane przez Zagładę. Kryterium uznania w postaci najwyższej rangi nagród wydaje się również zawodne, gdy wziąć pod uwagę statystyki, przykładowo, dotyczące Nagrody Nobla. Odsetek kobiet wśród nagrodzonych we wszystkich dziedzinach to jedynie 5 proc.! Stąd też trudności w interpretacji wyjątkowej pozycji Marii Skłodowskiej-Curie - aż dwukrotnej jej laureatki ${ }^{8}$.

Stan cywilny i sytuacja rodzinna -instytucja małżeństwa albo wspiera aktywność kobiet w poznaniu naukowym, pozwalając na transformację (transgresję?) (dzieje się tak w przypadku związku partnerskiego),

${ }^{8}$ Nobel Prize Awarded Women, dostępne przez: http://www.nobelprize.org/nobel prizes/lists/women.html (30.07.2013); Elżbieta Pakszys, Maria Skłodowska-Curie wśród uczonych kobiet swojej epoki. Próba analizy generacyjnej, [w:] red. Piotr Orlik, Krzysztof Przybyszewski, Filozofia a sfera publiczna, Wydawnictwo Naukowe Instytutu Filozofii UAM, Poznań 2012, s. 531-540. 
albo ją wyklucza, bądź ogranicza, w sytuacji konfliktu wyznawanych przez małżonków wartości. Najlepiej poznanym przykładem jest oczywiście przypadek małżeństwa Marii i Piotra Curie, będący niemal modelowym związkiem dwojga uczonych. Także u większości kobiet drugiego pokolenia szkoły lwowsko-warszawskiej ważnym czynnikiem rozwoju kariery naukowej były partnerskie małżeństwa, zawierane z mężczyzną pracującym w ramach tej samej lub pokrewnej dyscypliny. Za przykład niech posłużą Maria i Stanisław Ossowscy oraz Janina i Tadeusz Kotarbińscy.

Aktywność kobiet w poznaniu rozsadza więc konwencjonalne, patriarchalne małżeństwo z tradycyjnym układem podległości płci. Albo też badaczki unikają więzów matrymonialnych, realizując się w stanie panieńskim. To przypadki Józefy Joteyko i Marii Antoniny Czaplickiej. Nieliczna obecność dzieci, rzadkie macierzyństwo (właściwie tylko samotne rodzicielstwo Marii Skłodowskiej-Curie) wskazują na ograniczanie tej roli na rzecz samorealizacji w obranej sferze zawodowej i poznawczej.

Siostrzeństwo, solidarność oraz przyjaźń kobiet to czynnik słabo jeszcze rozpoznany, choć wydaje się istotny w realizacji wieloletniego przedsięwzięcia, jakim bywa wybitna kariera naukowa. Ma on najczęściej swój początek w rodzinie, wśród rodzeństwa, w relacji matka-córka, nauczycielka-uczennica i sprawdza się w sytuacjach szczególnie trudnych pod względem kulturowym i obyczajowym, na przykład przy przekraczaniu pewnych społecznych tabu. Wybitny przykład i tu stanowi Maria Skłodowska-Curie, do pewnego stopnia także Józefa Joteyko. Frapującym przypadkiem siostrzanej relacji wydaje się związek Róży Luksemburg z Zofią (Sonią) Liebknecht, zwłaszcza w świetle jej więziennej korespondencji ${ }^{9}$. Podanie kolejnych przykładów wymagałoby wnikliwej analizy osobistych relacji między chociażby przedstawicielkami pierwszego i drugiego pokolenia szkoły lwowsko-warszawskiej, co jest niestety mało prawdopodobne wobec braku odpowiednich materiałów.

Przykładów pozytywnych więzi między kobietami można upatrywać również w powracającej relacji mistrzyni-uczennica/e, której swoisty przykład stanowi relacja rodzinna Marii Skłodowskiej-Curie i jej córki Ireny, dziedziczki całego dorobku podwójnej noblistki, oraz inne ważne dla niej związki z kobietami. Czego, być może, odpowiednik dawałby się rozpoznać w charakterystycznej dla szkoły lwowsko-warszawskiej relacji mistrz-uczennica, zwłaszcza w drugim pokoleniu kobiet (choć nie bez - w jakimś stopniu - podtekstu erotycznego).

Przedstawiony obraz transgresji kobiet w nauce ukazuje ich drogę od pozycji podrzędnej i służebnej (asystentki, pomocnicy), przez bardziej samodzielną ,amatorkę”, do profesjonalistki dokonującej istotnych odkryć

9 Róża Luksemburg, Listy z więzienia, przekł. Maria Bilewiczowa, PIW, Warszawa 1982. 
w nauce. Stanowi on ilustrację możliwych dróg przekraczania granic, które lokują je na pozycjach naukowych coraz częściej równorzędnych z mężczyznami. Wydaje się, że właśnie w ten sposób transgresja indywidualna przechodzi w postać zbiorową.

\section{BIBLIOGRAFIA}

Davis Natalie Zemon, Metamorfozy. Maria Sybilla Merian, [w:] eadem, Kobiety na marginesach. Trzy siedemnastowieczne życiorysy, przeł. Bartosz Hlebowicz, Wydawnictwo Naukowe PWN, Warszawa 2012. Janion Maria, Kobiety i duch inności, Sic!, Warszawa 1996.

Kozielecki Józef, Transgresja i kultura, Wydawnictwo Akademickie „Żak”, Warszawa 1997. Luksemburg Róża, Listy z więzienia, przekł. Maria Bilewiczowa, PIW, Warszawa 1982.

Majewska Monika, Aktywizm wspótczesnej kobiety na tle koncepcji K. Popielskiego i J. Kozieleckiego, [w:] red. Irena Pufal-Struzik, O przekraczaniu granic własnych ograniczeń - perspektywa psychotransgresjonizmu, Impuls, Kraków 2008.

Mendecka Grażyna, Transgresyjna biografia Marii Skłodowskiej-Curie, [w:] red. Bogna Bartosz, Alicja Keplinger, Maria Straś-Romanowska, Transgresje - innowacje - twórczość, Wydawnictwo Uniwersytetu Wrocławskiego, Wrocław 2011.

Nobel Prize Awarded Women, dostępne przez: http://www.nobelprize.org/nobel_prizes/ lists/women.html (30.07.2013)

Pakszys Elżbieta, Danuta Sobczyńska, Przedmowa, [w:] red. eadem, Kobiety $w$ poznaniu naukowym wczoraj i dziś, seria Humanistyka i płeć, tom 2, Wydawnictwo Naukowe UAM, Poznań 1997.

Pakszys Elżbieta, Kobiety w filozofii polskiej. Dwa pokolenia kobiet Szkoły Lwowsko-Warszawskiej, [w:] red. Elżbieta Pakszys, Danuta Sobczyńska, Kobiety w poznaniu naukowym wczoraj i dziś, seria Humanistyka i pleć, tom 2, Wydawnictwo Naukowe UAM, Poznań 1997.

Pakszys Elżbieta, Maria Skłodowska-Curie wśród uczonych kobiet swojej epoki. Próba analizy generacyjnej, [w:] red. Piotr Orlik, Krzysztof Przybyszewski, Filozofia a sfera publiczna, Wydawnictwo Naukowe Instytutu Filozofii UAM, Poznań 2012.

Pakszys Elżbieta, Przekraczanie granic: uwarunkowania sukcesu kobiet $w$ Poznaniu, „Etyka” 2012, $\mathrm{nr} 45$.

Pufal-Struzik Irena, Wewnętrzne i zewnętrzne bariery przedsiębiorczości i twórczego rozwoju kobiet z perspektywy transgresjonizmu, [w:] red. Bogna Bartosz, Alicja Keplinger, Maria Straś-Romanowska, Transgresje - innowacje - twórczość, Wydawnictwo Uniwersytetu Wrocławskiego, Wrocław 2011. 